\title{
Parametric assessment of hydrochemical changes associated to underground pumped hydropower storage
}

\author{
Estanislao Pujades $^{\mathrm{a}, \mathrm{c}, *}$, Anna Jurado ${ }^{\mathrm{b}, \mathrm{c}}$, Philippe Orban $^{\mathrm{c}}$, Alain Dassargues ${ }^{\mathrm{c}}$ \\ a Department of Computational Hydrosystems, UFZ - Helmholtz Centre for Environmental Research, Permoserstr. 15, 04318 Leipzig, Germany \\ ${ }^{\mathrm{b}}$ Institute for Groundwater Management, Technische Universität Dresden, 01062 Dresden, Germany \\ ${ }^{c}$ Hydrogeology and Environmental Geology, Geo3, Dpt ArGEnCo, Aquapole, University of Liege, 4000 Liege, Belgium
}

\section{A R T I C LE INFO}

Article history:

Received 20 September 2018

Received in revised form 23 November 2018

Accepted 8 December 2018

Available online $\mathrm{xxx}$

Editor: Damia Barcelo

Keywords:

Abandoned mine

Reactive transport

Groundwater

Numerical modeling

\begin{abstract}
A B S T R A C T
Underground pumped hydropower storage (UPHS) using abandoned mines is an alternative to store and produce electricity in flat regions. Excess of electricity is stored in form of potential energy by pumping mine water to a surface reservoir. When the demand of electricity increases, water is discharged into the mine (i.e., underground reservoir) through turbines producing electricity. During the complete operational process of UPHS plants, hydrochemical characteristics of water evolve continuously to be in equilibrium successively with the atmosphere (in the surface reservoir) and the surrounding porous medium (in the underground reservoir). It may lead to precipitation and/or dissolution of minerals and their associated consequences, such as $\mathrm{pH}$ variations. Induced hydrochemical changes may have an impact on the environment and/or the efficiency (e.g., corrosions and incrustations affect facilities) of UPHS plants. The nature of the hydrochemical changes is controlled by the specific chemical characteristics of the surrounding porous medium. However, the magnitude of the changes also depends on other variables, such as hydraulic parameters. The role of these parameters is established to define screening criteria and improve the selection procedure of abandoned mines for constructing UPHS plants.

This work evaluates the role of the main hydrogeological factors for three different chemical composition of the porous medium. Results are obtained by means of numerical reactive transport modeling. Potential impacts on the environment (mainly on groundwater and surface water bodies) and on the efficiency of the UPHS plants vary considerably from a hydraulic parameter to another showing the need for a detailed characterization before choosing locations of future UPHS plants.
\end{abstract}

\section{Introduction}

Energy Storage Systems (ESSs) are essential to improve the efficiency and the utilization of renewable energies (Gebretsadik et al., 2016). ESSs allow storing the electricity generated during low demand energy periods and releasing it when energy consumption increases (Delfanti et al., 2015; Mason, 2015). Pumped Storage Hydropower (PSH) is the most worldwide used EES (Zhang et al., 2016), probably, because it allows storing and producing large amounts of electricity with a maximum efficiency. PSH stores electricity in the form of potential energy by means of two reservoirs located at different elevations, which is usually achieved taking advantage on the topography. Consequently, PSH plants are located in areas with steep topographical gradients. The excess of electricity generated during low demand periods (by other sources of energy such as nuclear power, wind or solar) is used to pump water from the lower to the upper reservoir. During peak electricity consumption periods, water is discharged from the upper to the lower reservoir generating

\footnotetext{
* Corresponding author at: Department of Computational Hydrosystems, UFZ Helmholtz Centre for Environmental Research, Permoserstr. 15, 04318 Leipzig, Germany.

Email address: estanislao.pujades-garnes@ufz.de (E. Pujades)
}

electricity. Despite PSH is being widely used, it is limited by some factors: the necessity of a steep topography and the impacts on landscape (Düsterloh, 2017), land use, environment and society (re-locations may be needed) (Wong, 1996; Kucukali, 2014). These limitations, especially that related with the topography, have encouraged investigating new ESSs. Underground pumped hydropower storage (UPHS) is a potential alternative. UPHS plants consist of two reservoirs from which the lower one is underground while the upper one may be located on the surface or at shallow depth (Barnes and Levine, 2011). Indeed, they can be placed in flat regions because a special topography is not required (Meyer, 2013). An UPHS has in principle less surface impact on landscape and land use as at least, one of the reservoirs is underground. In addition, if an abandoned mine is used as underground reservoir (Pummer and Schüttrumpf, 2018), UPHS may help for a better economic transition for local communities after the cessation of mine activities. However, in this case considered here, concerns may arise about environmental impacts and efficiency of the plant linked to the water exchanges occurring between the underground reservoir and the surrounding porous medium.

The UPHS concept is not new (Tam et al., 1979) and opportunities for installing UPHS plants have been considered in Singapore (Wong, 1996), USA (Fosnacht, 2011; Martin, 2007; Severson, 2011), 
South Africa (Winde and Stoch, 2010a, 2010b; Khan and Davidson, 2017; Winde et al., 2017), Netherlands (Min, 1984; Braat et al., 1985), Germany (Beck and Schmidt, 2011; Luick et al., 2012; Madlener and Specht, 2013; Meyer, 2013; Zillmann and Perau, 2015; Alvarado et al., 2016), Belgium (Spriet, 2014; Poulain et al., 2016; Bodeux et al., 2017) or Spain (Menéndez et al., 2017). Impacts of the water exchanges on the groundwater flow conditions and on the UPHS efficiency evolution have been also investigated (Poulain et al., 2016; Pujades et al., 2016; Bodeux et al., 2017; Pujades et al., 2017a). Finally, Pujades et al. $(2017 \mathrm{~b}, 2018)$ have investigated quantitatively potential hydrochemical impacts induced by UPHS when abandoned mines are used as underground reservoirs. They have simulated chemical changes associated to UPHS as water tends to evolve chemically to reach chemical equilibrium with the atmosphere (in the surface reservoir) and with the surrounding porous medium (in the underground reservoir). Hydrochemical changes vary depending on the chemical composition of the porous medium. Pujades et al. (2018) studied them under three different scenarios that differed in the chemical composition of the porous medium. They consider the presence of only pyrite, pyrite and calcite or only calcite. The decrease of $\mathrm{pH}$ (in the reservoirs and in the porous medium) and the precipitation of schwertmannite and goethite may occur under the presence of pyrite, which is oxidized because discharged water in the underground reservoir introduces dissolved oxygen in groundwater. The effects of pyrite dissolution are mitigated if calcite, which is dissolved from the porous medium acting as a buffer, is also present in the porous medium. In this case, the $\mathrm{pH}$ slightly increases and calcite and ferrihydrite may precipitate in the surface reservoir. Finally, hydrochemical changes may also be relevant when only calcite is present in the porous medium. In this case, UPHS activity induces an increase of $\mathrm{pH}$, a dissolution of calcite in the porous medium and its precipitation in the surface reservoir.

Hydrochemical changes may produce, among others, $\mathrm{pH}$ variations and the precipitation or dissolution of minerals that are relevant in terms of environmental impacts and efficiency. Low $\mathrm{pH}$ may decrease the groundwater and associated surface water quality. In addition, corrosions or precipitation in pipes, turbines, pumps and concrete structures could impact the UPHS efficiency at mid- or long-term. Consequently, water chemistry changes induced by UPHS operation are probably one of the key issues to be considered in future plants feasibility studies. Parameters influencing these hydrochemical changes must be identified and investigated. That could be useful to define adequate screening criteria for selecting abandoned mines to be used as underground reservoirs.

The main objective of this work is to identify the role of the main hydrogeological factors on hydrochemical changes induced by UPHS. Reactive transport numerical modeling is used for simulating several scenarios with modified hydrogeological parameters.

\section{Materials and methods}

\subsection{Problem statement}

The main characteristics of the problem are defined in Fig. 1a. An underground cavity is chosen as underground reservoir with top and bottom located at 95 and $105 \mathrm{~m}$ depth respectively. The cavity is a $50 \times 50 \mathrm{~m}$ square box with a height of $10 \mathrm{~m}$. The thickness of the whole domain is $200 \mathrm{~m}$ and the water table in natural conditions is considered at 92.5 and $97.5 \mathrm{~m}$ depth at the upgradient and downgradient boundaries of the model respectively. As a result of this chosen set-up, the cavity is totally saturated in natural conditions and is located in the upper part of an unconfined porous medium. The total saturated thickness ranges between 107.5 (upgradient boundary) and $102.5 \mathrm{~m}$ (downgradient boundary). The boundaries of the modeled domain are chosen at $500 \mathrm{~m}$ distance from the cavity. Thus, the hydraulic gradient under natural conditions (i.e., before UPHS operation) is 0.005 (i.e., $5 \mathrm{~m}$ difference in water table elevation over a considered total length of the model). This hydraulic gradient will be varied for some simulations in order to establish its specific influence on the water chemical evolution.

\subsubsection{Pumping/discharge frequencies}

The actual future frequency of pumping and discharge phases cannot be known in advance as it depends on numerous factors (Pujades et al., 2018). Therefore, day/night cycles are considered defining regular pumping and discharge phases allowing to obtain representative results for prediction. Pumping and discharge rates are assumed to be constant $\left(43,000 \mathrm{~m}^{3} / \mathrm{d}\right)$ inducing a decrease (during pumping) and an increase (during discharge) of the hydraulic head inside the underground reservoir up to $8.6 \mathrm{~m}$.

\subsubsection{Chemical features of the surrounding porous medium}

Three different hypotheses are considered for describing the chemical composition of the surrounding porous medium:

- The porous medium contains $1 \%$ of pyrite (Hypothesis H1): pyrite is a common sulfide mineral (Tabelin et al., 2017a, 2017b) in coal mines (Akcil and Koldas, 2006). Oxidation of sulfide minerals in the porous medium produces a drop in $\mathrm{pH}$ and precipitation of minerals (goethite and schwertmannite).

- The porous medium contains $1 \%$ of pyrite and $30 \%$ of calcite (Hypothesis H2): coal formations may be surrounded by or contain layers and/or lenses of carbonate rocks (Sharma et al., 2013; Campaner et al., 2014; Xu et al., 2018). Effects produced by pyrite oxidation can then be counterbalanced by dissolution of carbonate minerals. $\mathrm{pH}$ tends to increase and minerals precipitate in the surface reservoir (calcite and ferrihydrite) and are dissolved/oxidized (pyrite and calcite) in the porous medium.

- The porous medium contains $30 \%$ of calcite (Hypothesis H3). In this case where limestone mines would be used for UPHS, hydrochemical changes are controlled by calcite and the partial pressure evolution of $\mathrm{CO}_{2}\left(\mathrm{pCO}_{2}\right)$. $\mathrm{pH}$ increases and calcite precipitates in the surface reservoir and is dissolved in the porous medium.

For all the three hypotheses, other minerals contained in the surrounding porous medium would be silicates having relatively low reaction rates (White and Brantley, 1995). Consequently, they are neglected in the reactive transport model. Note that these three considered hypotheses correspond to strong simplification of the reality as the geological media compositions are actually far more complex.

\subsection{Basic concepts}

The content of dissolved $\mathrm{O}_{2}$ increases when water is aerated in the surface reservoir. Dissolved $\mathrm{O}_{2}$ induces pyrite oxidation when the aerated water is subsequently discharged in the undeground cavity in contact with the surrounding porous medium. Different minerals may precipitate in the surface reservoir depending on the water $\mathrm{pH}$. If $\mathrm{pH}$ is higher than 6 , ferrihydrite $\left(\approx \mathrm{Fe}(\mathrm{OH})_{3}\right)$ precipitates. Pytire dissolution and ferrihydrite precipitation are defined in R1:

$\mathrm{FeS}_{2}+15 / 4 \mathrm{O}_{2}(\mathrm{aq})+7 / 2 \mathrm{H}_{2} \mathrm{O}$
$=\mathrm{Fe}(\mathrm{OH})_{3}(\mathrm{~s})+2 \mathrm{SO}_{4}^{2-}+4 \mathrm{H}^{+}$ 

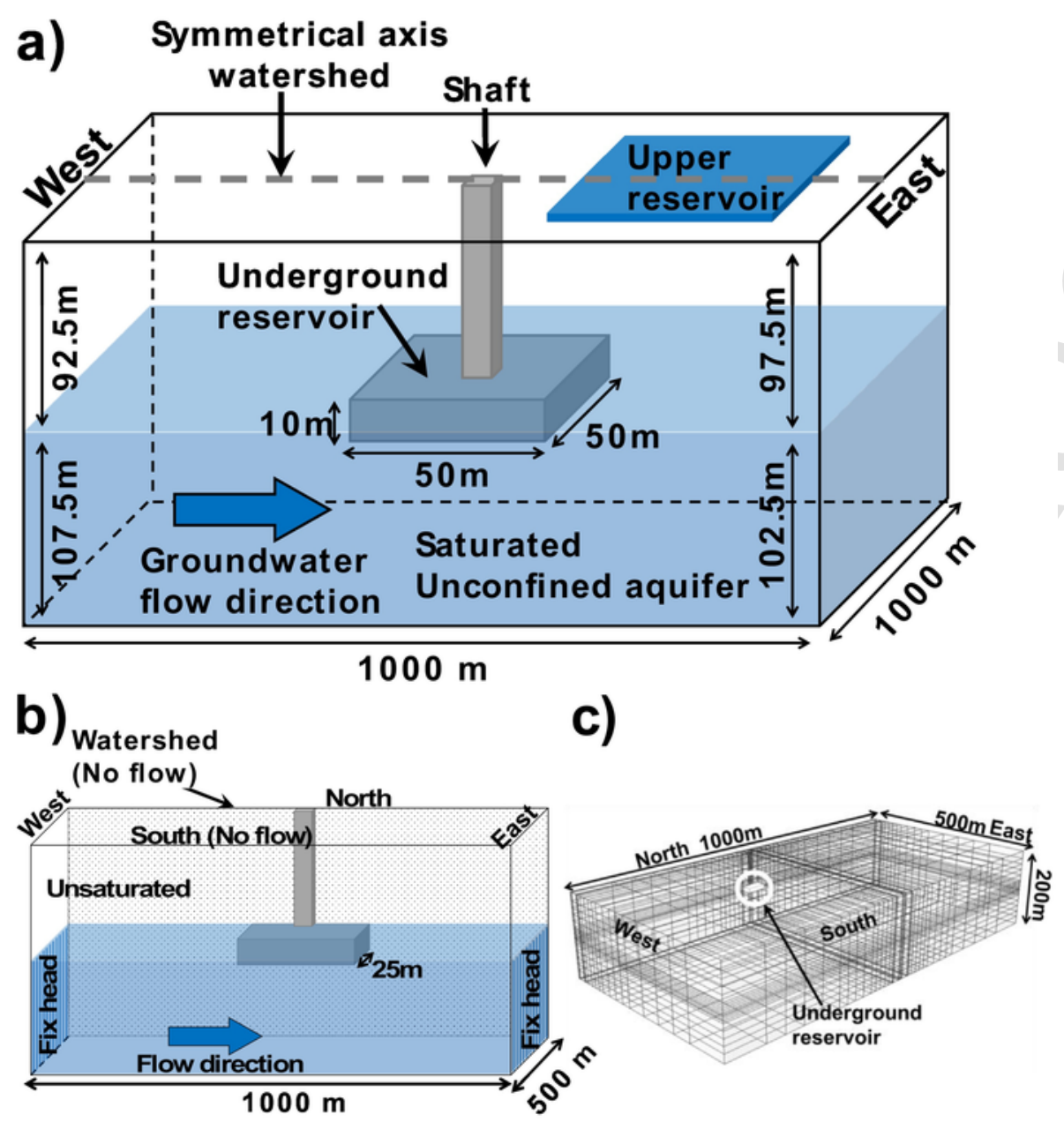

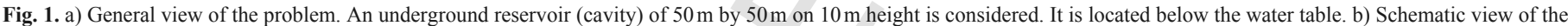
model domain. Half of the problem is modeled by taking advantage of the symmetry. c) View of the meshed numerical model.Modified from Pujades et al. (2018).

(R1)whileGoethite $\left(\mathrm{FeOOH}+3 \mathrm{H}^{+}\right)$precipitates for $\mathrm{pH}$ values between 4 and 6 (R2), and schwertmannite $\left(\mathrm{Fe}_{8} \mathrm{O}_{8}(\mathrm{OH})_{4.5}\left(\mathrm{SO}_{4}\right)_{1.75}\right)$ at $\mathrm{pH}$ values lower than 4 (R3) (Sánchez-España et al., 2011).

$$
\mathrm{Fe}^{3+}+2 \mathrm{H}_{2} \mathrm{O}=\mathrm{FeOOH}+3 \mathrm{H}^{+}
$$

$$
\begin{aligned}
& 8 \mathrm{Fe}^{3+}+12.5 \mathrm{H}_{2} \mathrm{O}+1.75 \mathrm{SO}_{4}^{2-} \\
& =\mathrm{Fe}_{8} \mathrm{O}_{8}(\mathrm{OH})_{4.5}\left(\mathrm{SO}_{4}\right)_{1.75}+20.5 \mathrm{H}^{+}
\end{aligned}
$$

Reactions $\mathrm{R} 1, \mathrm{R} 2$ and $\mathrm{R} 3$ reduce the $\mathrm{pH}$ and are characteristic of acid mine drainage processes (Banks et al., 1997; Robb, 1994) that produce well known adverse impacts on water resources (Plaza et al., 2017).

The following reaction occurs when calcite is considered (Hypotheses $\mathrm{H} 2$ and $\mathrm{H} 3$ ):

$$
\mathrm{CaCO}_{3}+2 \mathrm{H}^{+}=\mathrm{Ca}^{2+}+\mathrm{CO}_{2}(\mathrm{aq})+\mathrm{H}_{2} \mathrm{O}
$$

This reaction is not unidirectional and if $\mathrm{pCO}_{2}$ is modified (e.g., is exchanged with the atmosphere) calcite may precipitate or be dis- solved. $\mathrm{CO}_{2}$ and $\mathrm{O}_{2}$ are exchanged with the atmosphere in the surface reservoir as follows:

$$
\mathrm{CO}_{2}(\mathrm{aq})=\mathrm{CO}_{2}(\mathrm{~g})
$$

$\mathrm{O}_{2}(\mathrm{aq})=\mathrm{O}_{2}(\mathrm{~g})$

\subsection{System behavior}

Hypothesis H1. Groundwater in equilibrium with the porous medium has a null $\mathrm{pO}_{2}$ because it is consumed by pyrite oxidation. $\mathrm{pO}_{2}$ increases when water is pumped and stored in the surface reservoir as water composition evolves to reach chemical equilibrium with the atmosphere. Then, when this water is discharged into the underground cavity in contact with the porous medium, pyrite is oxidized following $\mathrm{R} 1$ and water $\mathrm{pH}$ decreases. The oxidation of pyrite stops when dissolved $\mathrm{O}_{2}$ is totally consumed. Pyrite oxidation also releases iron that may precipitate in the form of goethite (R2) or schwertmannite (R3), in the surface reservoir.

Hypothesis H2. Groundwater in equilibrium with the porous medium has a null $\mathrm{pO}_{2}$ (consumed by pyrite oxidation) and a high $\mathrm{pCO}_{2}$ (added during infiltration and circulation processes). $\mathrm{pO}_{2}$ increases 
and $\mathrm{pCO}_{2}$ decreases when water is pumped and stored in the surface reservoir (equilibrium with the atmosphere). The decrease of $\mathrm{pCO}_{2}$ induces a slight increase of $\mathrm{pH}$. Later, when water is discharged in the cavity in contact with the porous medium, $\mathrm{O}_{2}$ is consumed in pyrite oxidation, like in $\mathrm{H} 1$. The increase of $\mathrm{H}^{+}$induces the dissolution of calcite that acts as a buffer and prevents the $\mathrm{pH}$ to decrease. Oxidation of pyrite and dissolution of calcite release $\mathrm{Ca}^{2+}$ and iron that may precipitate in the form of calcite and ferrihydrite in the surface reservoir.

Hypothesis H3. Groundwater in equilibrium with the porous medium has a high $\mathrm{pCO}_{2}\left(\mathrm{CO}_{2}\right.$ increases as a consequence of infiltration and circulation processes). When water is pumped and stored in the surface reservoir, the $\mathrm{pCO}_{2}$ decreases, and consequently, $\mathrm{pH}$ increases. This process also induces precipitation of calcite. Later, when water is discharged, $\mathrm{pCO}_{2}$ increases in contact with the carbonate porous medium and groundwater, which induces calcite dissolution.

These chemical processes occur in many abandoned mines and their surrounding media as observed by Johnson and Hallberg (2005). The range of time that water remains in each reservoir may varyi between few minutes up to almost $24 \mathrm{~h}$ (a part of the total volume of water may be pumped at the beginning of the pumping period and discharged at the end of the discharge period and vice-versa). Thus, it is possible to consider that the average time that water molecules remain in each reservoir is about $12 \mathrm{~h}$. This mean duration is enough to explain the occurring reactions. It is also assumed here that groundwater $\mathrm{pO}_{2}$ and $\mathrm{pCO}_{2}$ reach chemical equilibrium with the atmosphere when water is stored in the upper reservoir. This assumption is reasonable because water is not stagnant and is mostly moving in the surface reservoir. Anyway, if water $\mathrm{pO}_{2}$ and $\mathrm{pCO}_{2}$ do not reach completely chemical equilibrium with the atmosphere in the upper reservoir, chemical reactions are the same but their consequences are mitigated as shown in Pujades et al. (2018).

\subsection{Numerical model}

PHAST code (Parkhurst et al., 1995; Parkhurst and Kipp, 2002) is used to perform the numerical simulations. This code solves reactive transport problems in porous media coupling PHREEQC (Parkhurst, 1995; Parkhurst and Appelo, 1999) and HST3D (Kipp, 1987, 1997). Due to the symmetry of the defined domain along a West-East axis, only half of the whole domain is actually modeled (Fig. 1). The modeled domain is divided in 15,600 elements. The element size is decreasing towards the underground cavity (Fig. 1c). A period of 30 days is simulated because long computation times are generally required (see Section 2.4.5). Nevertheless, 30 days is a long enough period to achieve the main objectives of this work.

\subsubsection{Flow boundary conditions}

Dirichlet boundary conditions (BCs) (i.e., prescribed head) are implemented at the Western and Eastern boundaries while no-flow is assumed through the North and the South boundaries (Fig. 1b). The head is prescribed at a depth of 92.5 and $97.5 \mathrm{~m}$ at the Western and Easter boundaries, respectively. Prescribed head values are modified in some scenarios to assess the influence of the hydraulic gradient: head is then prescribed at depths of 90 and $100 \mathrm{~m}$ on the Western and Eastern boundaries respectively, defining a 0.01 hydraulic gradient. Flow BCs are implemented inside the underground cavity for simulating pumping and discharges with a rate of $21,500 \mathrm{~m}^{3} / \mathrm{d}$ (note that this rate is the half than specified above because only the half of the problem is modeled). This rate produces an $8.6 \mathrm{~m}$ difference of water level in the underground cavity during half a day. The modeled un- derground reservoir is not supposed to be totally drained in order to avoid numerical problems. A drawdown of $8.6 \mathrm{~m}$ ensures that, at least, one of the nodes where flow BCs are applied remains saturated (the deeper one).

The numerical model assumes that the mine is flooded at the beginning. This assumption is maybe not so realistic with actual conditions where it is needed to rehabilitate the cavity and install the needed facilities (pipes, pumps, turbines...) before starting the activity of the UPHS plant. However, during those preparation works, groundwater would be most probably pumped from the cavity and stored in the surface reservoir. It means that this water is the previous mine water exposed to a chemical equilibrium with the atmosphere. This is thus similar to the first cycle of our model. Therefore, the difference between our model and the reality is the duration of the first cycle but not the behavior of the system or the chemical composition of pumped and discharged waters.

\subsubsection{Hydrochemical conditions and transport boundary conditions}

The hydrochemical and transport BC's are chosen according to the considered hypotheses. Groundwater that (1) is initially present in the whole modeled domain (i.e., in the underground cavity and in the surrounding porous medium), (2) enters through the west boundary, and (3) initially flows out through the east boundary, is considered in equilibrium with pyrite for $\mathrm{H} 1$, with pyrite and calcite for $\mathrm{H} 2$ and with calcite for $\mathrm{H} 3$. In addition, it is prescribed that groundwater under natural conditions has a $\mathrm{CO}_{2}$ partial pressure $\left(\mathrm{pCO}_{2}\right)$ of $10^{-2}$ atm for $\mathrm{H} 2$ and H3 (Faimon et al., 2012; Sanz et al., 2011).

\subsubsection{Modeling hydrochemical reactions}

Pyrite oxidation is calculated using the kinetic law described by Williamson and Rimstidt (1994) and considering a specific surface area of $1000 \mathrm{~m}^{-1}$. The kinetics of calcite reactions are implemented in the model using the kinetic law defined by Plummer et al. (1978) and considering a specific surface area of $45.3 \mathrm{~m}^{-1}$. Thermodynamic data for aqueous speciation and mineral and gas solubility are taken from the Minteq database, as implemented in the PHREEQC code (Parkhurst and Appelo, 1999). The solubility properties of schwertmannite are taken from Sánchez-España et al. (2011).

\subsubsection{Simulated scenarios}

Varying hydraulic conductivity $(K)$, porosity $(\theta)$, dispersivity $(D)$ and hydraulic gradient $\left(i_{N}\right)$ values, their respective influences are calculated by comparing simulated results to a reference scenario. The chosen characteristics of the reference scenarios are as follows: $K, \theta$, and $i_{N}$ are $0.01 \mathrm{~m} / \mathrm{d}\left(1.16 \times 10^{-7} \mathrm{~m} / \mathrm{s}\right), 0.05(5 \%)$, and $0.005(0.5 \%)$ respectively. $D$ is assumed to be $10 \mathrm{~m}$ in the flow direction and $1 \mathrm{~m}$ in the transversal directions. For each hypothesis, reference scenarios are named as $\mathrm{H} 1 . R, \mathrm{H} 2 . R$ and $\mathrm{H} 3 . R$ respectively. $K$ is increased in scenarios H1.K, H2.K and H3.K, $\theta$ is increased in H1. $\theta, \mathrm{H} 2 . \theta$ and H3. $\theta, i_{N}$ is increased in $\mathrm{H} 1 . i_{N}, \mathrm{H} 2 . i_{N}$ and $\mathrm{H} 3 . i_{N}$, while $D$ is reduced in scenarios $\mathrm{H} 1 . D, \mathrm{H} 2 . D$ and H3.D. Table 1 summarizes the considered characteristics for all simulated scenarios.

The characteristics of the underground cavity/reservoir are chosen the same for all the scenarios with $\theta=1, K=100,000 \mathrm{~m} / \mathrm{d}$ and $D=10,000 \mathrm{~m}$. The high values of these last parameters account for simulating that any discharged water in the cavity would be mixed homogeneously and instantaneously in the underground reservoir. This assumption does not influence significantly the simulated results (Pujades et al., 2017b).

The water temperature is assumed constant in all the simulations and equal to $10^{\circ} \mathrm{C}$ corresponding to a local average annual temperature (i.e., in Walloon Region of Belgium) and in agreement with the 
Table 1

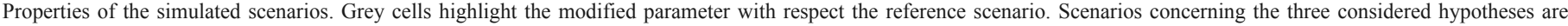
shown.

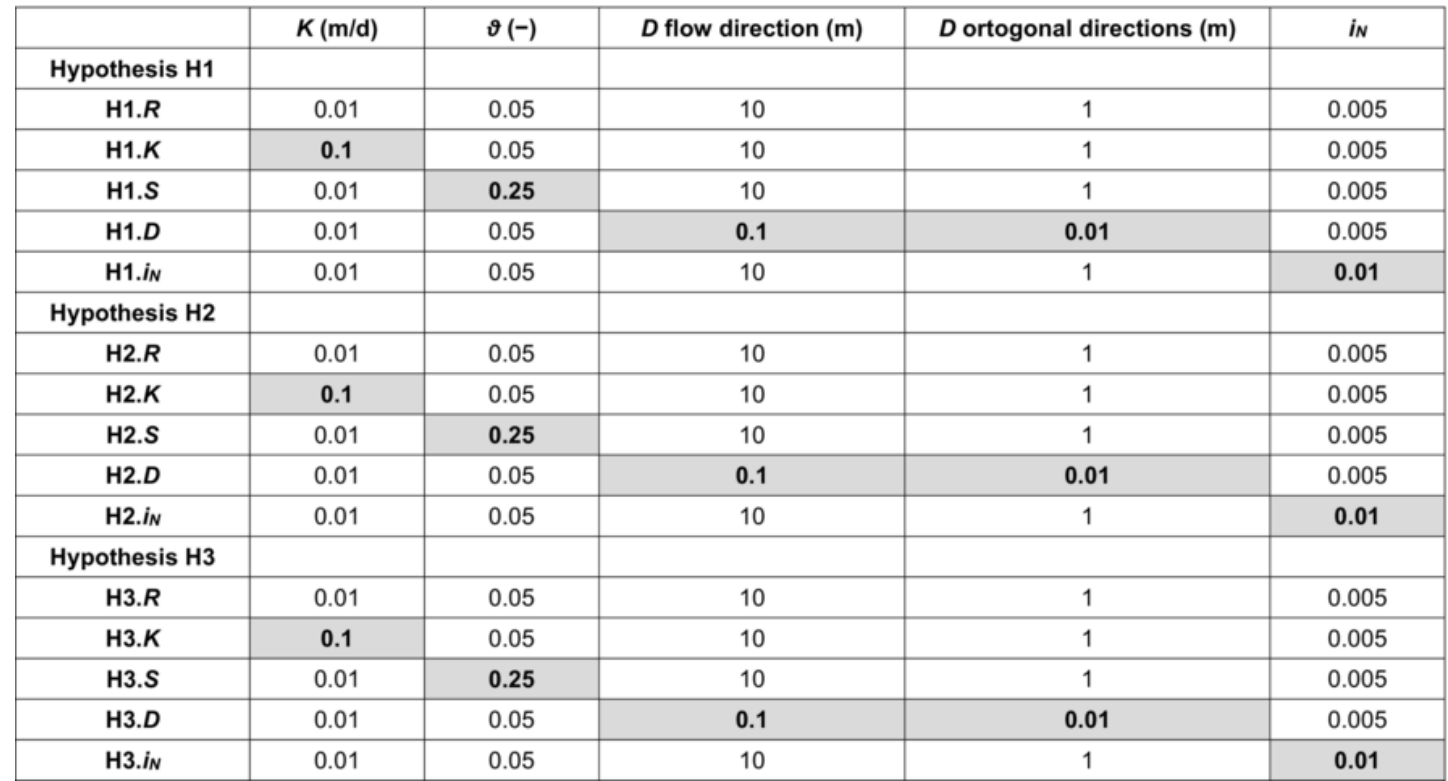

measured groundwater temperatures in the same region (Jurado et al., 2018). The surface temperature may influence the concentration of dissolved gasses in the surface reservoir, and therefore, the magnitude of the hydrochemical changes. Effects of surface temperature are not considered in this work. However, results concerning the influence of the surface temperature are included in the Appendix A, where two scenarios representing the summer and winter seasons are compared with the reference scenarios. Water temperature changes induced by friction and heat losses are not considered because these temperature changes would not affect significantly the results about the respective influences of the hydraulic parameters.

\subsubsection{Simulation strategy}

A challenging aspect is to simulate the water chemical evolution during successive pumping/discharging cycles because the chemical composition of the discharged water cannot be predicted in advance. The chemistry of the discharged water depends on the previously pumped water that is aerated in the surface reservoir before to be discharged. Thus, successive iterations with increasing simulated periods are performed following the same procedure than Pujades et al. (2018). The chemical characteristics of the discharged water are derived from the previous iteration results and are reintroduced in each iteration. The main particularity is that iterations must start from time 0 because the code used does not allow reintroducing the available volume of minerals in the porous medium. Consequently, the computational time increases exponentially with the simulated time (i.e., more than two weeks are needed to simulate 30 days). If the iterations were restarted after each pumping period, the available volume of minerals in the porous medium would remain constant.

\section{Results}

Computed $\mathrm{pH}$ and mineral evolutions for the different scenarios and hypotheses are displayed in Appendix B. Global hydrochemical behavior of water in the reservoirs and in the porous medium is not discussed in this paper since it has been previously described by Pujades et al. (2018). This work is focused on the differences (which are shown in percentage) between the reference scenarios and those in which parameters are modified. A positive difference means that computed results are higher than those obtained for the reference scenario while differences are negative when they are lower. The evolution of the difference between scenarios is shown during the complete simulated period. Table 2 summarizes the difference with respect to the reference scenario at the last simulated time step.

\subsection{Surface and underground reservoirs}

\subsection{1. $\mathrm{pH}$ behavior}

Fig. 2 displays computed differences of $\mathrm{pH}$ in the surface reservoir with respect to the reference scenarios. Results are shown for the three considered hypotheses. High values of $K, \theta$ and $D$ (note that $D$ is decreased in the scenarios $\mathrm{H} 1 . D, \mathrm{H} 2 . D$ and $\mathrm{H} 3 . D$ ) promote the increase of $\mathrm{pH}$ in $\mathrm{H} 1$ and $\mathrm{H} 2$. Conversely, $\mathrm{pH}$ does not change when $K, \theta, D$ are modified in $\mathrm{H} 3$. The increase of $i_{N}$ only slightly modifies the $\mathrm{pH}$ in $\mathrm{H} 1$ while it does not vary in $\mathrm{H} 2$ and $\mathrm{H} 3$. Fig. 3 shows the results concerning the $\mathrm{pH}$ evolution in the underground reservoir. High values of $K, \theta$ and $D$ promote the increase of $\mathrm{pH}$ in $\mathrm{H} 1$ ( $K$ and $D$ slightly modify the results). In hypotheses $\mathrm{H} 2$ and $\mathrm{H} 3$, the largest differences are observed during early times (except in $\mathrm{H} 2 . \theta$ ) when $K, \theta$ and $D$ are modified. $\mathrm{pH}$ decreases when $K, \theta$ and $D$ are reduced. During later times of these scenarios, $\mathrm{pH}$ evolves to be equal (or very similar) to that computed for the reference scenario. The only observed exception occurs in the scenario $\mathrm{H} 2 . \theta$, in which $\mathrm{pH}$ is lower during early times and higher during late times with respect to the reference scenario. The computed $\mathrm{pH}$ response is the same than in the surface reservoir when $i_{N}$ is increased.

The maximum differences with respect to the reference scenarios occur when $\theta$ is modified. These are around $+5 \%$ in $\mathrm{H} 1$ (both reservoirs), +0.43 (surface reservoir) and $-1.3 \%$ (underground reservoir) in $\mathrm{H} 2$ and $-1.5 \%$ (underground reservoir) in $\mathrm{H} 3$.

\subsubsection{Precipitation of minerals in the surface reservoir}

Fig. 4 refers to the precipitated mass of minerals in the surface reservoir. Schwertmannite and goethite precipitate for H1. Goethite 
Table 2

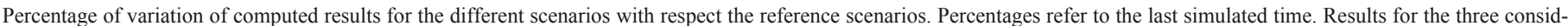
ered hypotheses are shown.

\begin{tabular}{|c|c|c|c|c|c|c|c|c|c|}
\hline \multirow[t]{2}{*}{ Scenario } & \multirow[t]{2}{*}{ Variable } & \multirow[t]{2}{*}{ Value } & \multicolumn{2}{|c|}{$\mathrm{pH}$ reservoirs } & \multicolumn{2}{|c|}{ Precipitation surface reservoir } & \multirow[t]{2}{*}{$\mathrm{pH}$ medium } & \multicolumn{2}{|c|}{ Dissolution medium } \\
\hline & & & Surface & Underground & Goethite & Schwermannite & & Pyrite & \\
\hline H1. $K$ & $K$ & $\uparrow$ & 1.61 & 2.29 & -0.89 & 8.89 & -18.40 & 157.00 & \\
\hline H1. $\theta$ & $\theta$ & $\uparrow$ & 4.23 & 6.41 & -14.17 & 39.54 & 25.40 & 42.40 & \\
\hline $\mathrm{H} 1 . D$ & $D$ & $\downarrow$ & -0.96 & -1.37 & 3.00 & -6.72 & 65.80 & -98.80 & \\
\hline $\mathrm{H} 1 . i_{N}$ & $i_{N}$ & $\uparrow$ & 0.08 & 0.08 & -0.46 & 0.56 & 0.49 & -1.55 & \\
\hline \multirow[t]{2}{*}{ Scenario } & Variable & Value & \multicolumn{2}{|c|}{$\mathrm{pH}$ reservoirs } & \multicolumn{2}{|c|}{ Precipitation surface reservoir } & $\mathrm{pH}$ medium & \multicolumn{2}{|c|}{ Dissolution medium } \\
\hline & & & Surface & Underground & Calcite & Ferrihidryte & & Pyrite & Calcite \\
\hline $\mathrm{H} 2 . K$ & $K$ & $\uparrow$ & 0.16 & 0.03 & 12.66 & -0.57 & 0.98 & 172.00 & 184.00 \\
\hline $\mathrm{H} 2 . \theta$ & $\theta$ & $\uparrow$ & 0.44 & 0.85 & 35.66 & -1.41 & -0.20 & 70.70 & 216.00 \\
\hline $\mathrm{H} 2 . D$ & $D$ & $\downarrow$ & -0.09 & -0.10 & -5.67 & 0.24 & -0.23 & -98.90 & -96.60 \\
\hline $\mathrm{H} 2 . i_{N}$ & $i_{N}$ & $\uparrow$ & 0.00 & 0.00 & 0.37 & -0.02 & -0.01 & -1.26 & -0.73 \\
\hline \multirow[t]{2}{*}{ Scenario } & Variable & Value & \multicolumn{2}{|c|}{$\mathrm{pH}$ reservoirs } & \multicolumn{2}{|c|}{ Precipitation surface reservoir } & $\mathrm{pH}$ medium & \multicolumn{2}{|c|}{ Dissolution medium } \\
\hline & & & Surface & Underground & Calcite & & & Calcite & \\
\hline $\mathrm{H} 3 . K$ & $K$ & $\uparrow$ & 0.00 & -0.10 & 10.21 & & 1.25 & 182.00 & \\
\hline $\mathrm{H} 3 . \theta$ & $\theta$ & $\uparrow$ & 0.00 & -0.02 & 27.68 & & -0.24 & 224.00 & \\
\hline $\mathrm{H} 3 . D$ & $D$ & $\downarrow$ & 0.00 & 0.00 & -4.47 & & -0.27 & -96.20 & \\
\hline $\mathrm{H} 3 . i_{N}$ & $i_{N}$ & $\uparrow$ & 0.00 & 0.00 & 0.30 & & -0.01 & -0.87 & \\
\hline
\end{tabular}

only precipitates during the first pumping/discharge cycle while schwertmannite precipitates during the rest of the simulation (Pujades et al., 2018). Mass of precipitated schwertmannite increases with high $K, \theta$, $D$ and $i_{N}$ (slightly). The influence of the considered parameters is the opposite when the precipitated mass of goethite is regarded. Greatest differences are observed when the $\theta$ value is modified. At the end of the simulation time, precipitated mass of schwertmannite increases by $40 \%$ and that of goethite decreases by $15 \%$ for H1. $\theta$. Calcite and ferrihydrite precipitate in the surface reservoir for $\mathrm{H} 2$. Precipitated mass of calcite increases with high $K, \theta, D$ and $i_{N}$ (slightly), while the opposite behavior is observed for the precipitated mass of ferrihydrite. The slightly influence of $i_{N}$, which is difficult to deduce from Fig. 4, can be observed in Table 2. The most relevant parameter for calcite and ferrihydrite precipitation is $\theta$. The mass of precipitated calcite increases by $35 \%$ while ferrihydrite precipitation decreases by $1.4 \%$ in H2. $\theta$. Finally, only calcite precipitates in H3. Mass of precipitated calcite increases for high $K, \theta, D$ and $i_{N}$ (slightly). Greatest differences are observed for H3. $\theta(+30 \%)$.

\subsection{Porous medium}

\subsection{1. $\mathrm{pH}$ behavior}

Fig. 5 shows the results concerning the $\mathrm{pH}$ behavior in the porous medium. $\mathrm{pH}$ is considered downgradient at $15 \mathrm{~m}$ from the underground reservoir. $\mathrm{pH}$ clearly increases with high values of $\theta$ and low values of $D$ and decreases when the value of $K$ is raised for H1, while the influence of these parameters is opposite for Hypotheses $\mathrm{H} 2$ and $\mathrm{H} 3$. Greatest variations with respect to $\mathrm{H} 1 . R$ are observed for $\mathrm{H} 1 . D(+60 \%)$. When Hypotheses $\mathrm{H} 2$ and $\mathrm{H} 3$ are considered, greatest differences with respect to the reference scenarios occur in $\mathrm{H} 2 . K$ and H3.K $(+1 \%)$. The influence of $i_{N}$ is not clearly observed in Fig. 5 because differences are slight $(+0.5 \%$ for $\mathrm{H} 1$ and $-0.01 \%$ for $\mathrm{H} 2$ and $\mathrm{H} 3$ ). $\mathrm{pH}$ increases in $\mathrm{H} 1$ and decreases in $\mathrm{H} 2$ and $\mathrm{H} 3$ when $i_{N}$ is incremented.

\subsubsection{Dissolution of minerals}

Finally, results concerning the dissolved/oxidized minerals in the porous medium are displayed in Fig. 6. Dissolved/oxidized minerals are computed downgradient at $5 \mathrm{~m}$ from the underground reservoir. Oxidized/dissolved minerals are pyrite $(\mathrm{H} 1)$, calcite and pyrite $(\mathrm{H} 2)$ and calcite (H3) (Pujades et al., 2018). Influence of $K, \theta, D$ and $i_{N}$ varies depending on the hypothesis. The mass of oxidized pyrite increases in $\mathrm{H} 1$ and $\mathrm{H} 2$ when $K, \theta$ and $D$ are incremented. In the same manner, dissolved mass of calcite increases with higher values of $K, \theta$ and $D$ for Hypotheses $\mathrm{H} 2$ and H3. Masses of oxidized/dissolved minerals slightly decrease in all hypotheses when $i_{N}$ is increased. At the end of the simulated time (Table 2), the greatest variations with respect to the reference scenarios, are as follows: 1) the oxidized mass of pyrite is $\approx 160 \%$ and $\approx 170 \%$ higher when $K$ is increased in $\mathrm{H} 1$ and $\mathrm{H} 2$, respectively, and 2) the dissolved mass of calcite is $\approx 220 \%$ higher when the porosity is increased in $\mathrm{H} 2$ and $\mathrm{H} 3$.

\section{Discussion}

\subsection{Assessment of the impacts of modifying $K$ (scenarios H1.K, H2.K and $\mathrm{H} 3 . \mathrm{K}$ )}

Water exchanges (between the underground reservoir and the surrounding porous medium) increase and indeed more water flows through the porous medium when $K$ is increased. As a result, more water from the surface reservoir with high $\mathrm{pO}_{2}$ and low $\mathrm{pCO}_{2}$ reaches the porous medium (downgradient side) and thus more minerals can be dissolved/oxidized. For this reason, $\mathrm{pH}$ in the surrounding porous medium (Fig. 5) decreases in $\mathrm{H} 1$ and increases in $\mathrm{H} 2$ and $\mathrm{H} 3$. Concerning the reservoirs (Fig. 3), $\mathrm{pH}$ increases in $\mathrm{H} 1 . \mathrm{K}$ because of the increased portion of groundwater from the upgradient side (less affected by the UPHS operation and in equilibrium with the porous medium). Groundwater from the upgradient side has a higher $\mathrm{pH}$ than groundwater from the downgradient side. $\mathrm{pH}$ also increases in the reservoirs for $\mathrm{H} 2 . \mathrm{K}$ because more calcite and less ferrihydrite precipitate. Finally, $\mathrm{pH}$ only varies slightly in the underground reservoir for $\mathrm{H} 3$. In this case, $\mathrm{pH}$ is lower than that computed for H3.R because groundwater from the upgradient side has lower $\mathrm{pH}$ than groundwater from the downgradient side (affected by precipitation and dissolution of calcite). 

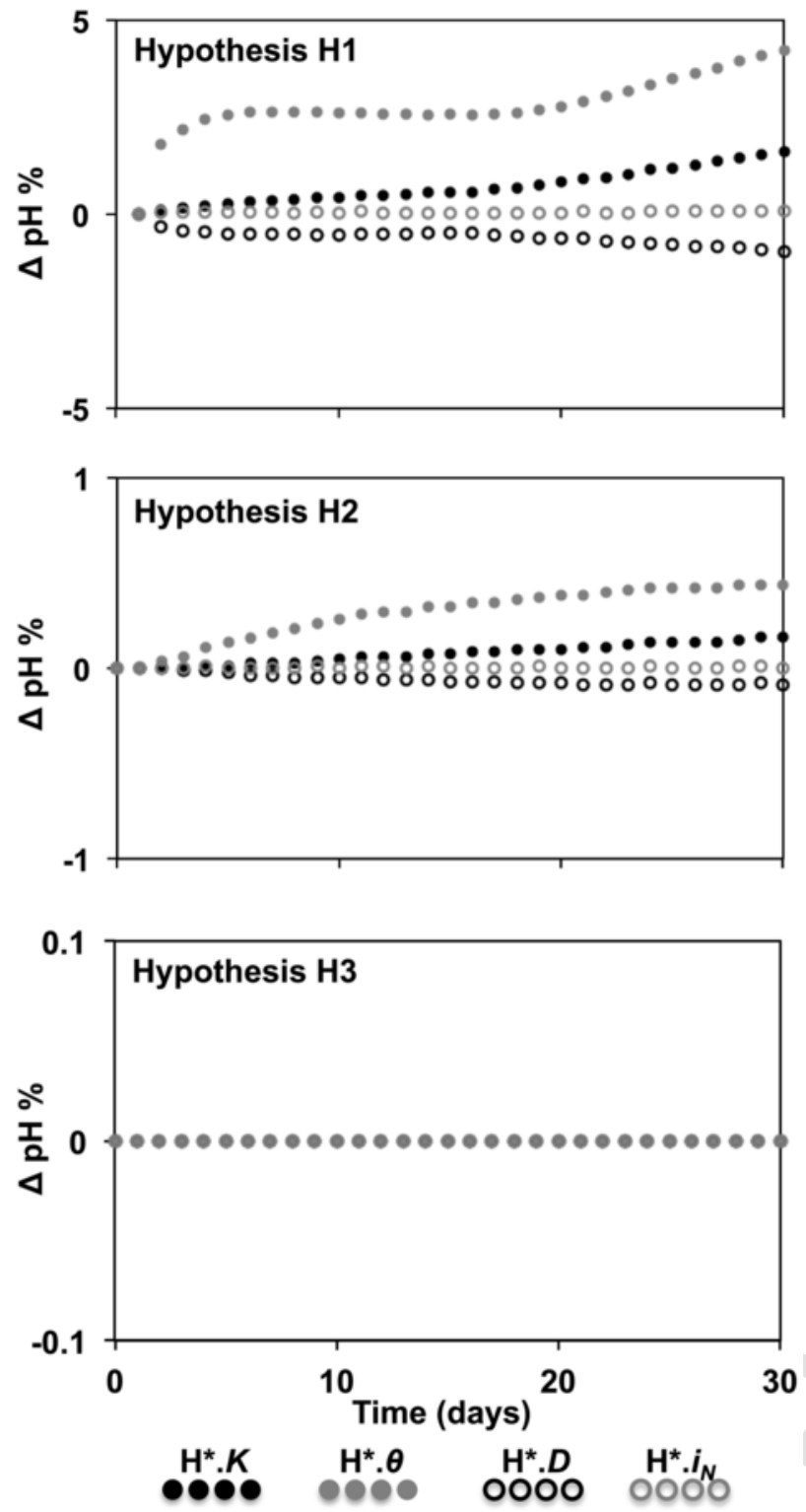

Fig. 2. Variation of the $\mathrm{pH}$ in the surface reservoir with respect to the reference scenarios. Results considering the three modeled hypotheses $(\mathrm{H} 1, \mathrm{H} 2$ and $\mathrm{H} 3)$ are shown.

The variation of $K$ also affects the mass of precipitated minerals in the surface reservoir (Fig. 4). The mass of goethite decreases and that of schwertmannite increases for H1.K. Given that goethite precipitates when $\mathrm{pH}$ ranges between 4 and 6 , precipitation may decrease because the $\mathrm{pH}$ in the surface reservoir is closer to the upper limit for H1.K than that in the reference scenario (H1.R). Similarly, the precipitation rate of schwertmannite decreases for $\mathrm{pH}$ lower than 2. Thus, the mass of precipitated schwertmannite increases because $\mathrm{pH}$ in the surface reservoir is higher for H1.K than that of H1.R. The volume of precipitated ferrihydrite slightly decreases with respect the reference scenario for Hypothesis $\mathrm{H} 2$ when $K$ is raised. In this case, groundwater flowing from the upgradient side has less dissolved iron than groundwater from the downgradient side, then, less ferrihydrite can precipitate. Finally, mass of precipitated calcite increases in H2.K and H3.K because groundwater from the upgradient side has a higher $\mathrm{pCO}_{2}$ than that from the downgradient side.
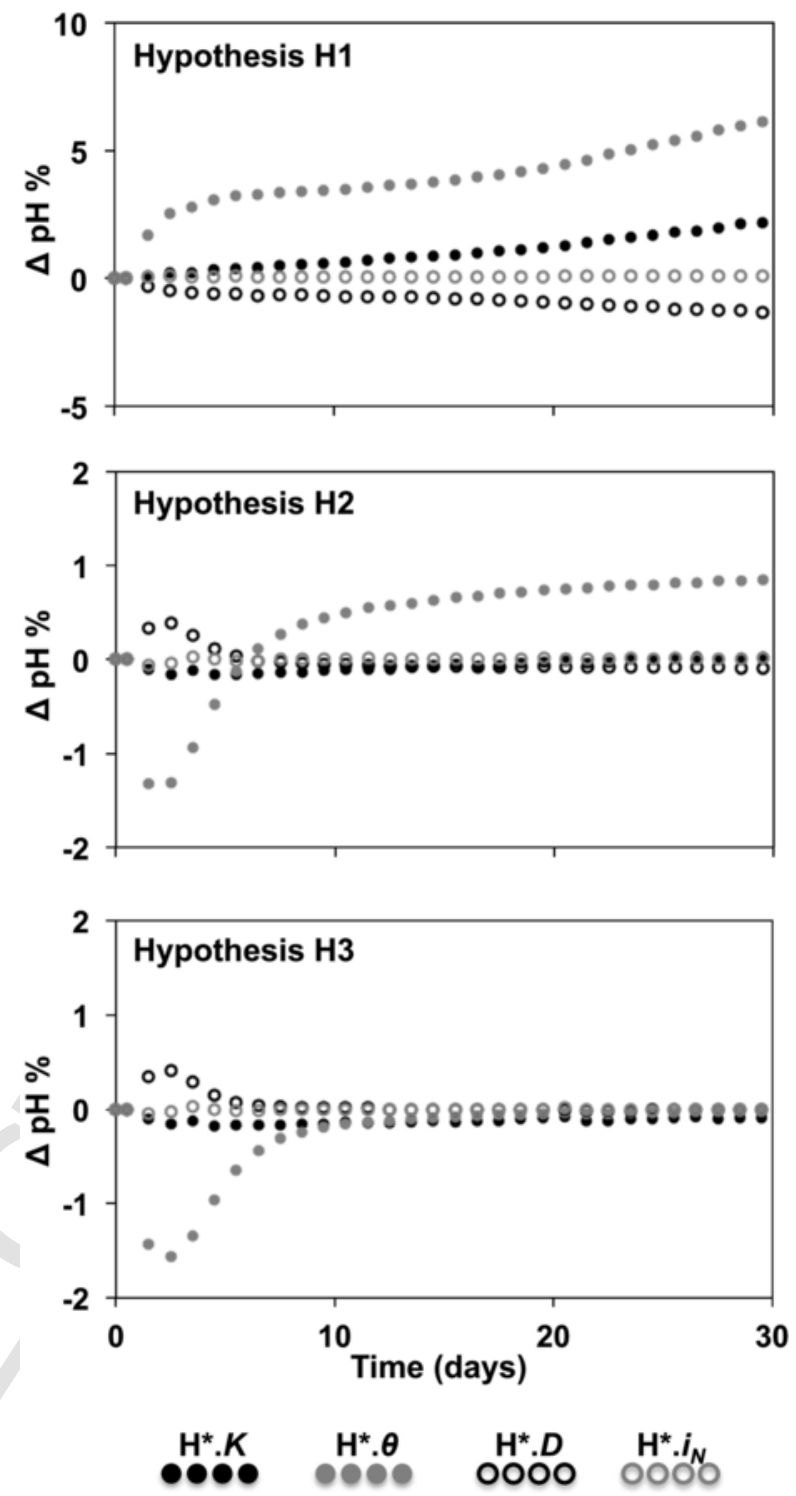

Fig. 3. Variation of the $\mathrm{pH}$ in the underground reservoir with respect to the reference scenarios. Results considering the three modeled hypotheses (H1, H2 and H3) are shown.

\subsection{Assessment of the impacts of modifying $\theta$ (scenarios $\mathrm{H} 1 . \theta, \mathrm{H} 2 . \theta$ and $\mathrm{H} 3 . \theta$ )}

Available surface of minerals (pyrite and/or calcite) per unitary volume of porous medium increases when the value of $\theta$ is incremented. As a result, more minerals (calcite and pyrite) are available to be dissolved/oxidized. However, the increase of the dissolved/oxidized mass of minerals is not reflected in the $\mathrm{pH}$ behavior because the volume of groundwater in equilibrium with the porous medium (i.e., natural conditions) per unitary volume of porous medium also increases. Consequently, hydrochemical changes are mitigated due to a dilution effect. Therefore, although the mass of dissolved pyrite increases in $\mathrm{H} 1 . \theta$ with respect $\mathrm{H} 1 . R, \mathrm{pH}$ in the surrounding medium is higher than that in the reference scenario (Fig. 5). The same occurs for $\mathrm{H} 2 . \theta$ and $\mathrm{H} 3 . \theta$. In these hypotheses, $\mathrm{pH}$ in the surrounding porous medium is lower than that in the reference scenarios (Fig. 5). 

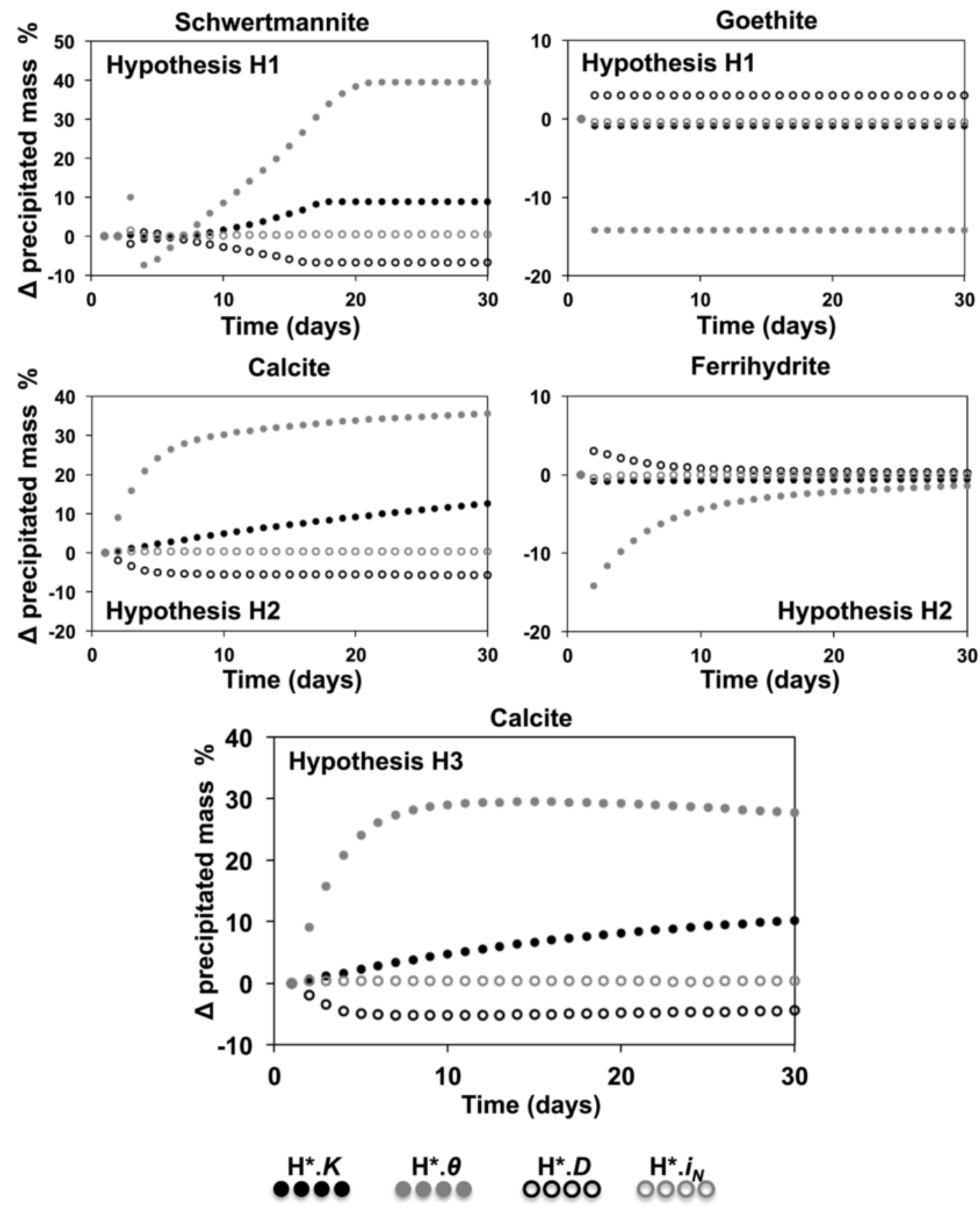

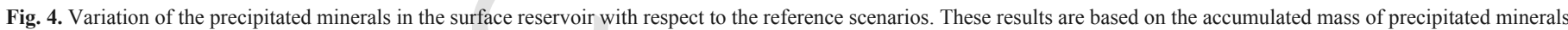
in the surface reservoir. Results considering the three modeled hypotheses (H1, H2 and H3) are shown.

Water exchanges (between the porous medium and the reservoirs), and thus, groundwater entering in the underground reservoir from the upgradient side increases when $\theta$ is incremented. Thus, more water in equilibrium with the porous medium (i.e., not affected by UPHS) reaches the reservoirs. This water has higher values of $\mathrm{pH}$ than that from the downgradient side in $\mathrm{H} 1$. Consequently, $\mathrm{pH}$ in the reservoirs (Figs. 2 and 3) tends to increase with respect to the reference scenario. In $\mathrm{H} 2$, dissolved iron and calcium that are available to precipitate as ferrihydrite and calcite, respectively, are higher when the groundwater is not affected by UPHS (i.e., groundwater from the upgradient ide). For this reason, $\mathrm{pH}$ would tend to increase in $\mathrm{H} 2 . \theta$ with respect to $\mathrm{H} 2 . R$, although the opposite behavior is observed during early times. By contrast, $\mathrm{pH}$ in $\mathrm{H} 3 . \theta$ does not vary noticeably with respect to the reference scenario ( $\mathrm{pH}$ is only lower in the underground reservoir during early times). In this case, upgradient groundwater, with lower $\mathrm{pH}$ than groundwater from the downgradient side, would mitigate the $\mathrm{pH}$ increase in the reservoirs produced by calcite precipitation.

Mass of precipitated minerals (Fig. 4) evolves as expected when $\theta$ is increased. Less goethite and more schwertmannite precipitate because $\mathrm{pH}$ is higher in $\mathrm{H} 1 . \theta$ than in $\mathrm{H} 1 . R$. In $\mathrm{H} 2 . \theta$, precipitated ferrihydrite decreases and that of calcite increases with respect to H2. $R$ because the volume of upgradient groundwater reaching the reservoirs increases (upgradient groundwater has less dissolved iron and 

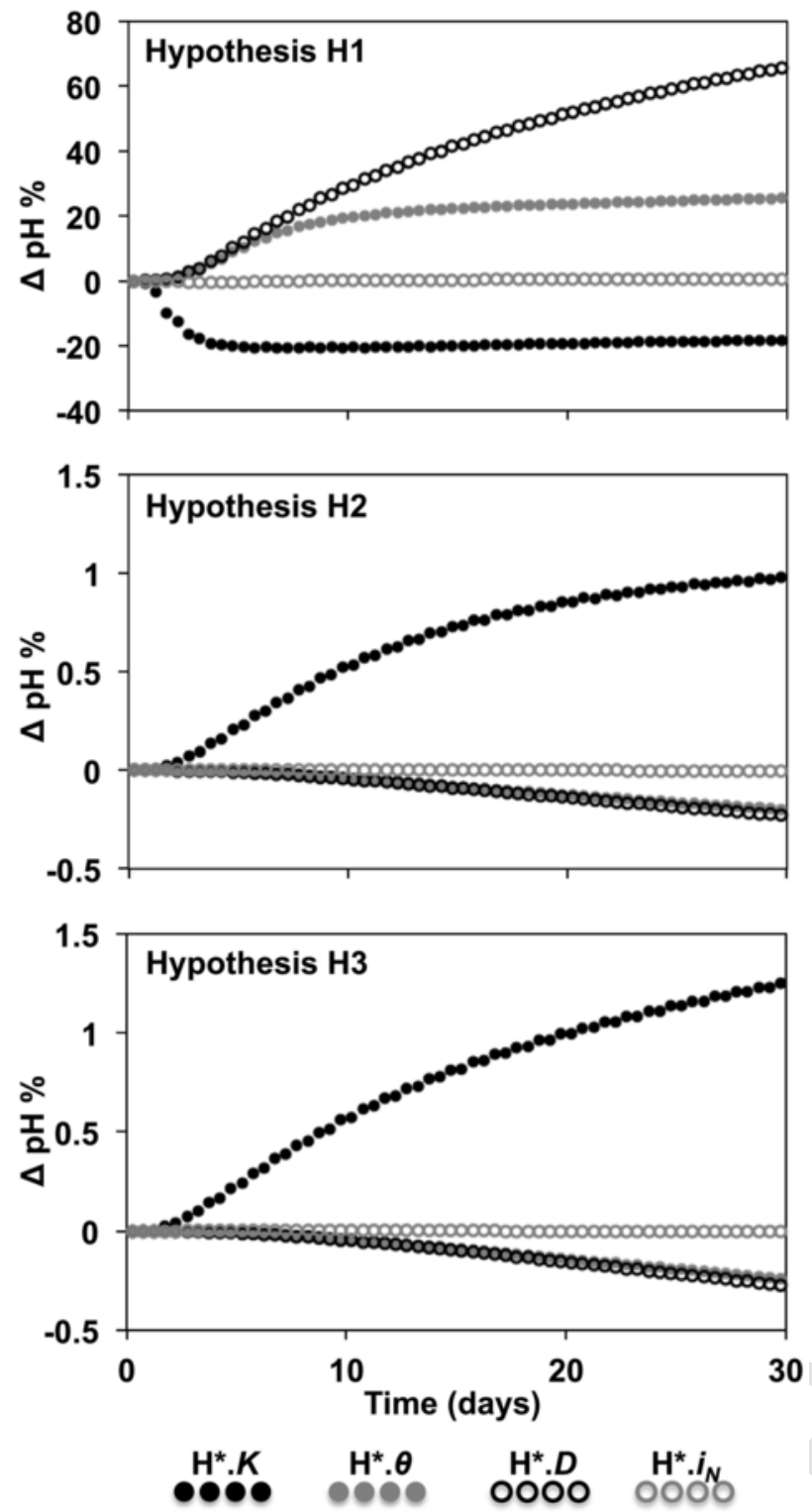

Fig. 5. Variation of the $\mathrm{pH}$ in the surrounding porous medium with respect to the reference scenarios. Results considering the three modeled hypotheses $(\mathrm{H} 1, \mathrm{H} 2$ and $\mathrm{H} 3)$ are shown. $\mathrm{pH}$ is computed at an observation point located at $15 \mathrm{~m}$ downstream from the underground reservoir.

more or equal $\mathrm{pCO}_{2}$ than downgradient groundwater). For the same reason, the mass of precipitated calcite increases in $\mathrm{H} 3 . \theta$ with respect to H3.R.

\subsection{Assessment of the impacts of modifying D (scenarios H1.D, H2.D} and $\mathrm{H} 3 . \mathrm{D})$

The portion of porous medium affected by the discharged water decreases when the value of $D$ is lowered. As a result, less pyrite and calcite are dissolved/oxidized in H1.D, H2.D and H3.D (Fig. 6). Thus, $\mathrm{pH}$ in the surrounding porous medium (Fig. 5) is higher in H1.D and lower in H2.D and H3.D than in the reference scenarios. The lowering of $D$ decreases the influence of groundwater not (or less) affected by the UPHS activity (i.e., $\mathrm{pH}=7, \mathrm{pCO}_{2}=10^{-2}$ atm and in equilibrium with the porous medium) on the water in the reservoirs. Consequently, $\mathrm{pH}$ in the surface and underground reservoirs de- creases for H1.D with respect to H1.R (Figs. 2 and 3). In addition, mass of precipitated goethite increases and that of schwertmannite decreases (Fig. 4). $\mathrm{pH}$ also decreases for $\mathrm{H} 2 . D$ (Fig. 2) because less water with high $\mathrm{pCO}_{2}$ reaches the reservoirs and less calcite precipitates (Fig. 4). Moreover, the mass of precipitated ferrihydrite increases, which contributes to a lowering of the $\mathrm{pH}$ (Figs. 2 and 4). Mass of precipitated calcite also decreases for H3.D (Fig. 4). However, $\mathrm{pH}$ in the reservoirs remains constant (Figs. 2 and 3 ) because calcite is the only mineral and water is equally in equilibrium with the atmospheric $\mathrm{pCO}_{2}$ as in $\mathrm{H} 3 . R$.

\subsection{Assessment of the impacts of modifying $i_{N}$ (scenarios $\mathrm{H} 1 . i_{N}, \mathrm{H} 2$.} $i_{N}$ and $\left.\mathrm{H} 3 . i_{N}\right)$

The smallest changes with respect to the reference scenarios occur when $i_{N}$ is incremented. More upgradient groundwater, not (or less) affected by UPHS activity, reaches the underground reservoir and its downgradient side. As a result, discharged water reaching the surrounding porous medium 1) is mixed with more groundwater flowing from the upgradient side, and 2) affects a bigger portion of aquifer than in the reference scenarios. Thus, mineral dissolutions occur over a larger area and the volume of dissolved minerals at the observation point decreases (Fig. 6). Given that the groundwater flow increases, the impacts on the surrounding porous medium are mitigated. $\mathrm{pH}$ in the surrounding medium (downgradient side) slightly increases for $\mathrm{H} 1 . i_{N}$ and slightly decreases for $\mathrm{H} 2 . i_{N}$ and $\mathrm{H} 3 . i_{N}$ (Fig. 5). The volume of upgradient groundwater reaching the underground reservoir increases with high values of $i_{N}$, which modifies the mass of precipitated minerals and the $\mathrm{pH}$ at the reservoirs (Figs. 2, 3 and 4). This fact is observed in $\mathrm{H} 1 . i_{N}$, in which the values of $\mathrm{pH}$ in the reservoirs are higher than those in H1.R (Figs. 2 and 3). In addition, the precipitated mass of goethite decreases and that of schwertmannite increases (Fig. 4) because the values of $\mathrm{pH}$ in the surface reservoir are higher than in the reference scenario. Changes with respect to the reference scenarios are not observed in Hypotheses $\mathrm{H} 2$ and $\mathrm{H} 3$ when the value of $i_{N}$ is raised.

\subsection{Efficiency of the UPHS plant and environmental impact}

Hydrochemical changes may impact on the environment and affect the efficiency of UPHS (Pujades et al., 2018). Note that the efficiency is not only considered from an energy point of view, in which the efficiency is defined from the difference between the input and output of electricity. A global concept of efficiency is considered, thus, if the UPHS plant must be stopped (e.g., for cleaning tasks), it is considered that the efficiency is affected. The most relevant aspects concerning environmental impacts are the $\mathrm{pH}$ changes (in the groundwater of the surrounding porous medium and in water of the surface reservoir) and the dissolution of minerals. Three aspects must be pointed out concerning the impacts on the efficiency: 1) precipitation of minerals in the surface reservoir (cleaning tasks affect the efficiency), 2) $\mathrm{pH}$ evolution in the reservoirs (low $\mathrm{pH}$ induces corrosion while high $\mathrm{pH}$ produces scaling), and 3 ) the dissolved minerals in the surrounding porous medium (efficiency of pumps and turbines depends on the water exchanges; Pujades et al., 2017a). Table 3 shows how impacts on the environment and efficiency vary for all simulations with respect to the reference scenario. Grey and black cells mean that the impact decreases and increases, respectively, while cells are white when the impact does not vary. We can observe that in most scenarios some specific aspects relative to environmental impacts or efficiency are improved while others are worsened. All factors relative to environmental impacts are only improved or 

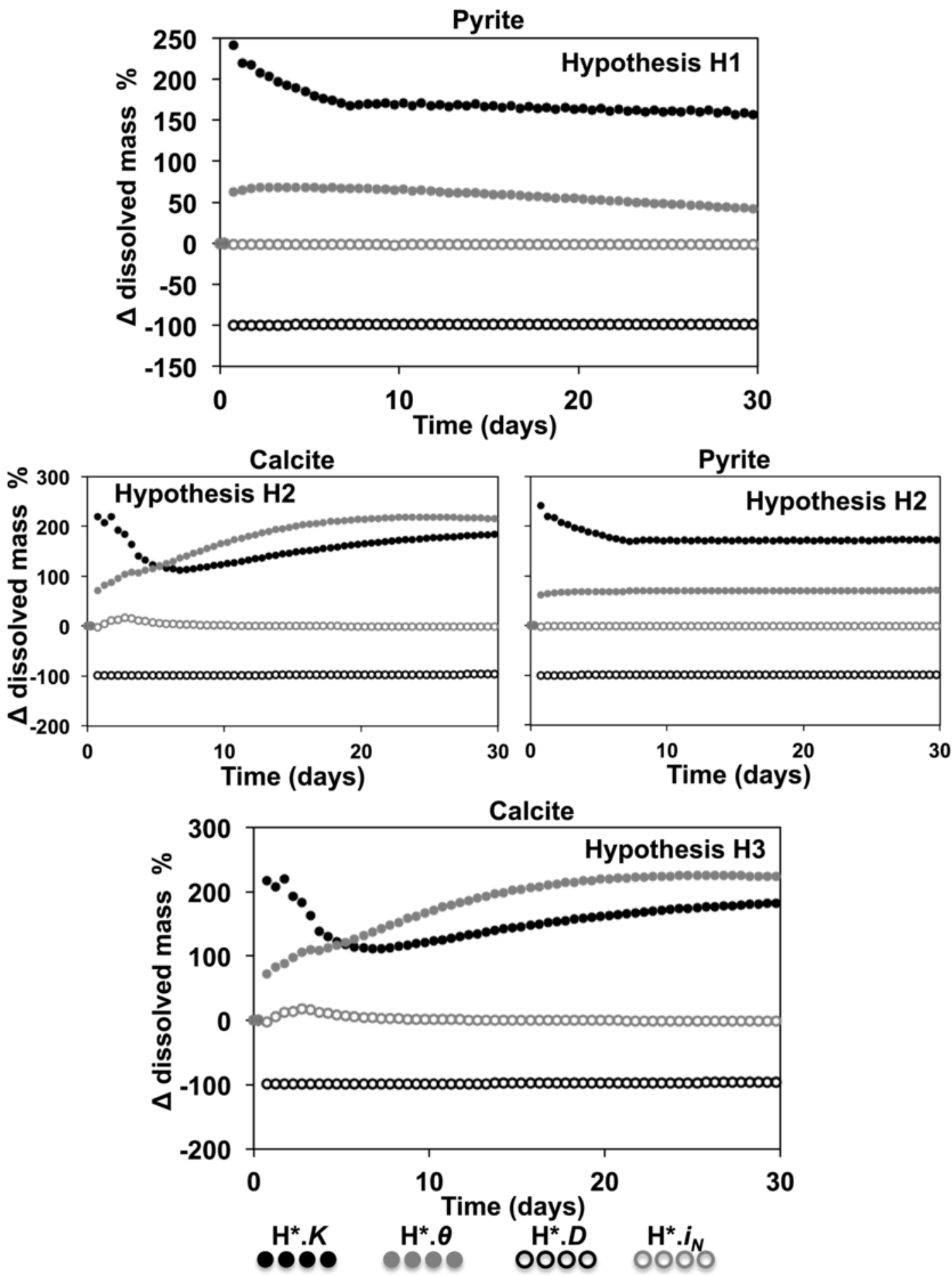

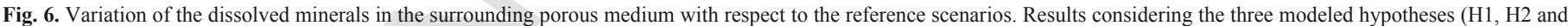
H3) are shown. Dissolved minerals are computed at an observation point located at $5 \mathrm{~m}$ distance downstream from the underground reservoir.

evenly-matched in four scenarios: H2.D, H2.i $i_{N}$, H3.D and H3.i. $i_{N}$. If it is assumed that $\mathrm{pH}$ values in the reservoirs and in the surrounding medium are the most important parameter to establish guidelines for minimizing impacts and optimizing efficiency. Thus, on the one hand, environmental impacts are reduced in 1) $\mathrm{H} 1$ for high values of $\theta$ and $\left.i_{N}, 2\right) \mathrm{H} 2$ for low values of $D$ and high of $i_{N}$, and 3) H3 for low values of $D$ and high of $\theta$ and $i_{N}$. On the other hand, efficiency is improved with 1) high values of $K, \theta$ and $i_{N}$ in $\mathrm{H1}$, 2) low values of $D$ and high of $i_{N}$ in $\mathrm{H} 2$, and 3) high values of $K, \theta$ and $i_{N}$ and low of $D$ in H3.

\subsection{Analysis of regression coefficients}

The most relevant parameters are assessed through the regression coefficient between the $\mathrm{pH}$ variations (with respect to the reference scenarios) and the degree of change of the different considered para- 
Table 3

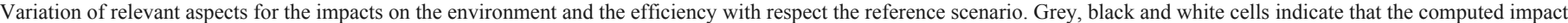
is lower, higher or equal, respectively, than that calculated for the reference scenarios. Results concerning the three considered hypotheses are shown.

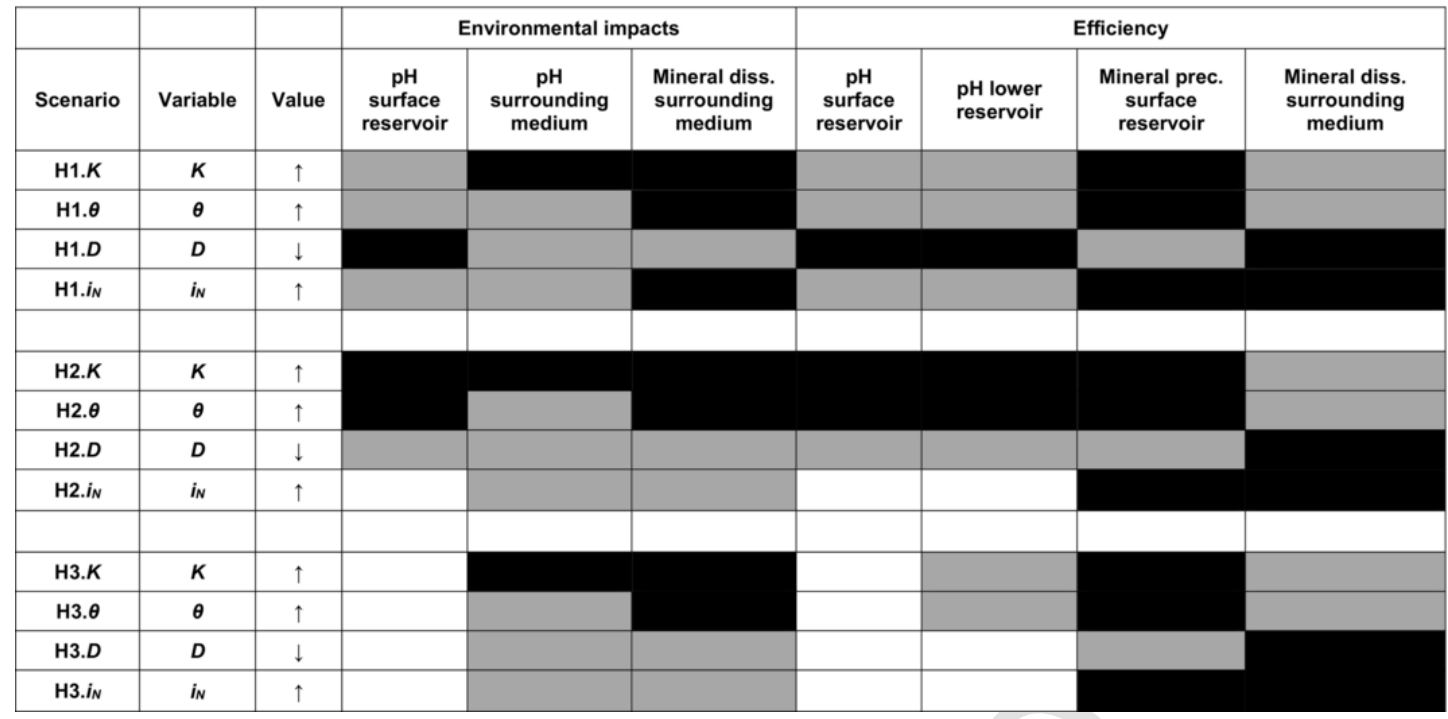

meters. In the same manner, the regression coefficient is used to analyze the locations (i.e., reservoirs or porous medium) where the influence of the considered parameters is meaningful (Fig. 7). High regression coefficients indicate that the influence of the considered parameter is high. The highest influence of the assessed parameters is observed in $\mathrm{H} 1 . \theta$ is the most determinant parameter and the highest variations of the $\mathrm{pH}$ with respect the reference scenario occur in the porous medium. The influence of the assessed parameters is slightly higher in the underground reservoir than in the surface one. Similarly, the most relevant parameter in $\mathrm{H} 2$ is $\theta$ and the highest influence of the evaluated parameters occurs in the porous medium. The only exception is observed in scenario H2. $\theta$. Concerning the reservoirs, the influence of the assessed parameters is higher in the underground cavity than in the surface one, except for H2.K. Finally, in H3, the most relevant parameter is $K$ and the highest influence of the assessed parameters is observed in the porous medium.

\section{Conclusions}

This study investigates how hydrochemical changes (and their consequences on the environment and operational efficiency) induced by UPHS operations might be dependent on different hydrogeological factors, such as the hydraulic conductivity, the porosity, the hydraulic gradient and/or the dispersivity. Other parameters such as the reactive surface of the minerals or the volume of water pumped and discharged are also relevant for the hydrochemical changes, but their influence has already been established (Pujades et al., 2018). Obviously, the synthetic model that is used here is not applicable as such to any real case-study. However, it allows simulating the influence of the considered parameters on the evolving water chemical characteristics and the results are useful for the selection of potential sites where constructing UPHS plants is considered.

The most relevant statements concerning the hydrochemical changes are the following: high hydraulic gradients $\left(i_{N}\right)$ and low dispersivities $(D)$ tend to mitigate environmental impacts while high hydraulic conductivities $(K)$, porosities $(\theta)$ and hydraulic gradients $\left(i_{N}\right)$ improve the efficiency. The influence of the considered parameters on hydrochemical changes varies depending on the chemical compo- sition of the surrounding porous medium (Fig. 7). The highest influences of the assessed parameters occur when only pyrite is contemplated (H1) while the lowest ones are obtained when only calcite is considered in the porous medium (H3). Results also show that the influence of the assessed parameters on the hydrochemical changes is higher in the porous medium than in the reservoirs. Finally, it is possible to deduce that the most influential parameters on the hydrochemical changes are $K$ and $\theta$. Consequently, these parameters should require special attention during the selection of potential sites for the construction of UPHS plants.

Evaluated parameters do not affect in the same way (positively or negatively) all the aspects relative to the environment or the efficiency. Thus, if a choice is possible between different abandoned mine sites to construct an UPHS, criteria can be adopted to select the most appropriate one. For example, if the main concern is the $\mathrm{pH}$ in the surface reservoir (due to an expected exchange with other surface water bodies), and if the surrounding porous medium contains pyrite (without calcite), it would be advisable to choose a site with the highest values of $K, \theta$ and $i_{N}$.

Results show that the magnitude of the hydrochemical changes depends on hydrogeological parameters. Consequently, a proper hydrogeological characterization will be essential for the construction of future UPHS plants. Reactive transport models will also be of paramount importance to predict the hydrochemical changes produced by UPHS.

Hadjipaschalis et al., 2009

Zillmann and Perau, 2015

\section{Acknowledgements}

E. Pujades and A. Jurado gratefully acknowledge the financial support from the University of Liège and the EU through the Marie Curie BeIPD-COFUND postdoctoral fellowship programme (2014-2016 and 2015-2017 "Fellows from FP7-MSCA-COFUND, 600405"). This research was supported by the Public Service of Wallonia - Department of Energy and Sustainable Building through the Smartwater project. 

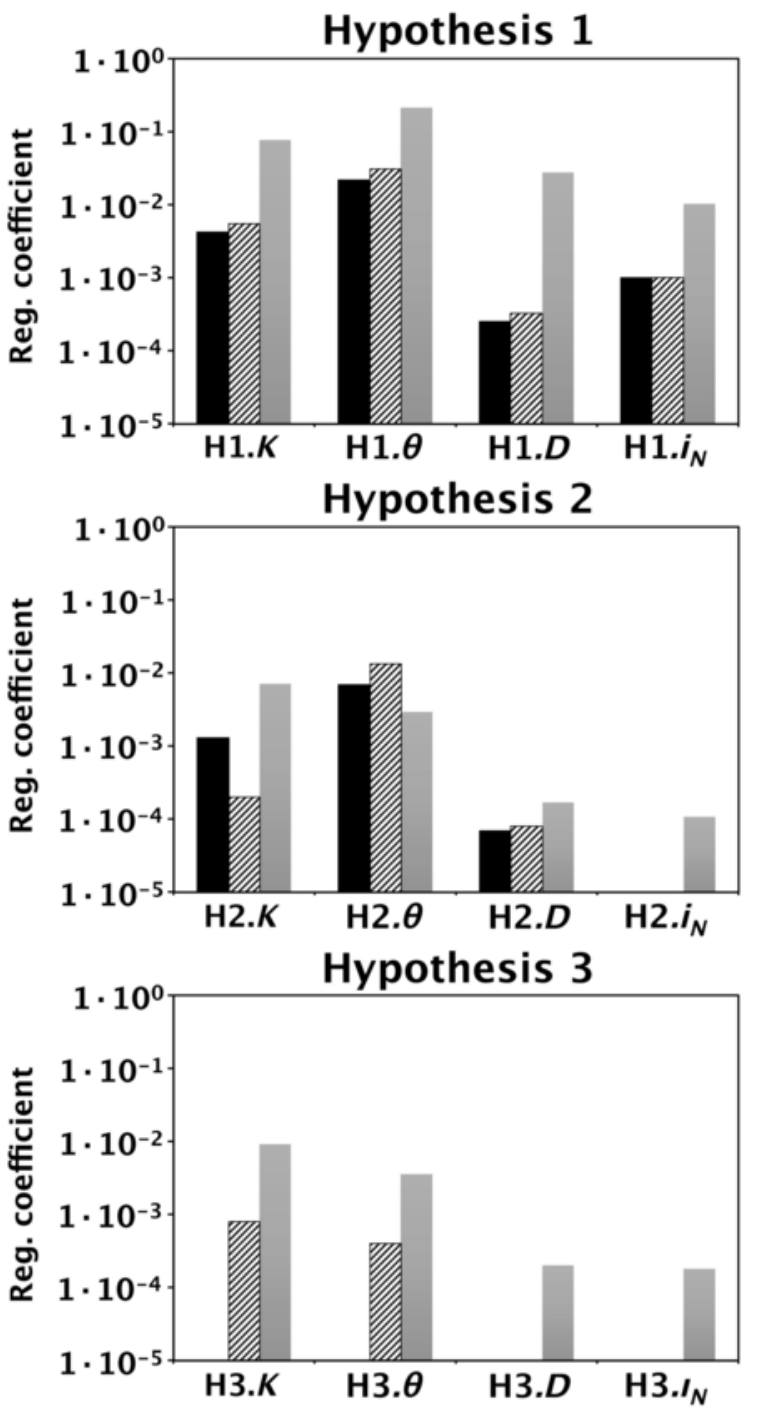

Underground reservoir WIISurface reservoir

Fig. 7.

\section{Appendix A. Supplementary data}

Supplementary data to this article can be found online at https:// doi.org/10.1016/j.scitotenv.2018.12.103.

\section{References}

Akcil, A., Koldas, S., 2006. Acid mine drainage (AMD): causes, treatment and case studies. J. Clean. Prod. 14, 1139-1145. https://doi.org/10.1016/j.jclepro.2004.09 006, (Improving Environmental, Economic and Ethical Performance in the Mining Industry. Part 2. Life cycle and process analysis and technical issues).

Alvarado, R., Niemann, A., Wortberg, T., 2016. Underground pumped-storage hydroelectricity using existing coal mining infrastructure. In: E-proceedings of the 36th IAHR World Congress.

Banks, D., Younger, P.L., Arnesen, R.-T., Iversen, E.R., Banks, S.B., 1997. Mine-water chemistry: the good, the bad and the ugly. Environ. Geol. 32, 157-174. https:// doi.org/10.1007/s002540050204

Barnes, F.S., Levine, J.G., 2011. Large Energy Storage Systems Handbook [WWW Document]. CRC Press https://www.crcpress.com/

Large-Energy-Storage-Systems-Handbook/Barnes-Levine/p/book/

9781420086003, (accessed 3.12.17).
Beck, H.P., Schmidt, M. (Eds.), 2011. Windenergiespeicherung durch Nachnutzung stillgelegter Bergwerke.

Bodeux, S., Pujades, E., Orban, P., Brouyère, S., Dassargues, A., 2017. Interactions between groundwater and the cavity of an old slate mine used as lower reservoir of an UPHS (underground pumped storage hydroelectricity): a modelling approach. Eng. Geol. 217, 71-80. https://doi.org/10.1016/j.enggeo.2016.12.007.

Braat, K.B., Van Lohuizen, H.P.S., De Haan, J.F., 1985. Underground pumped hydro-storage project for the Netherlands. Tunnels Tunneling 17 (11), 19-22.

Campaner, V.P., Luiz-Silva, W., Machado, W., 2014. Geochemistry of acid mine drainage from a coal mining area and processes controlling metal attenuation in stream waters, southern Brazil. An. Acad. Bras. Cienc. 86 (2), 539-554.

Delfanti, M., Falabretti, D., Merlo, M., 2015. Energy storage for PV power plant dispatching. Renew. Energy 80, 61-72. https://doi.org/10.1016/j.renene.2015.01.047.

Düsterloh, U., 2017. UPHES feasibility: EFZN case study from German ore mines. In: Science Business Society Dialogue Conference: Strengthening the Science Business Society Dialogue in the SADC Region, Johannesburg, South Africa, 28-30 November 2017. Academy of Science of South Africa http://research.assaf.org.za/ handle/20.500.11911/99? show $=$ full.

Faimon, J., Ličbinská, M., Zajíček, P., Sracek, O., 2012. Partial pressures of $\mathrm{CO}_{2}$ in epikarstic zone deduced from hydrogeochemistry of permanent drips, the Moravian Karst, Czech Republic. Acta Carsol. 41, https://doi.org/10.3986/ac.v41i1.47.

Fosnacht, D.R., 2011. (P.S.T.). Pumped Hydro Energy Storage (PHES) Using Abandoned Mine Pits on the Mesabi Iron Range of Minnesota - Final Report.

Gebretsadik, Y., Fant, C., Strzepek, K., Arndt, C., 2016. Optimized reservoir operation model of regional wind and hydro power integration case study: Zambezi basin and South Africa. Appl. Energy 161, 574-582. https://doi.org/10.1016/j.apenergy. 2015.09.077.

, . Renew. Sust. Energ. Rev.

Johnson, D.B., Hallberg, K.B., 2005. Acid mine drainage remediation options: a review. Sci. Total Environ. 338 (1-2), 3-14.

Jurado, A., Borges, A.V., Pujades, E., Briers, P., Nikolenko, O., Dassargues, A., Brouyère, S., 2018. Dynamics of greenhouse gases in the river-groundwater interface in a gaining river stretch (Triffoy catchment, Belgium). Hydrogeol. J. 1-13. https://doi.org/10.1007/s10040-018-1834-y.

Khan, S.Y., Davidson, I.E., 2017. Underground pumped hydroelectric energy storage in South Africa using aquifers and existing infrastructure. In: Schulz, D. (Ed.), NEIS Conference 2016. Springer Vieweg, Wiesbaden.

Kipp, K., 1987. HST3D; a Computer Code for Simulation of Heat and Solute Transport in Three-dimensional Ground-water Flow Systems. Government Documents.

Kipp, K.L., 1997. Guide to the Revised Heat and Solute Transport Simulator: HST3D Version 2.

Kucukali, S., 2014. Finding the most suitable existing hydropower reservoirs for the development of pumped-storage schemes: an integrated approach. Renew. Sust. Energ. Rev. 37, 502-508. https://doi.org/10.1016/j.rser.2014.05.052.

Luick, H., Niemann, A., Perau, E., Schreiber, U., 2012. Coalmines as Underground Pumped Storage Power Plants (UPP) - A Contribution to a Sustainable Energy Supply? Presented at the EGU General Assembly Conference Abstracts. 4205.

Madlener, R., Specht, J.M., 2013. An Exploratory Economic Analysis of Underground Pumped-storage Hydro Power Plants in Abandoned Coal Mines. FCN Working Paper No. 2/2013.

Martin, G.D., 2007. Aquifer Underground Pumped Hydroelectric Energy Storage. University of Wisconsin-Madison.

Mason, I.G., 2015. Comparative impacts of wind and photovoltaic generation on energy storage for small islanded electricity systems. Renew. Energy 80, 793-805. https://doi.org/10.1016/j.renene.2015.02.040.

Menéndez, J., Loredo, J., Fernandez, J.M., Galdo, M., 2017. Underground pumped-storage hydro power plants with mine water in abandoned coal mines in northern Spain. In: Wolkersdorfer, C., Sartz, L., Sillanpää, M., Häkkinen, A. (Eds.), Mine Water \& Circular Economy. vol. I, Lappeenranta University of Technology, Lappeenranta, Finland, pp. 6-14.

Meyer, F., 2013. Storing Wind Energy Underground. FIZ Karlsruhe - Leibnz Institute for Information Infrastructure, Eggenstein Leopoldshafen, Germany, (ISSN: 0937-8367).

Min, A.P.N., 1984. Ondergrondse Pomp Accumulatie Centrale: effectiviteitsverbetering d.m.v. verschillende pomp-turbinevermogens. TUDelft.

Parkhurst, D.L., 1995. User's guide to PHREEQE - a computer program for speciation, reaction-path, advective transport, and inverse geochemical calculations. In: US Geological Survey Water Resources Graphical User Interface for the Geochemical Computer Program Investigations Report.

Parkhurst, D.L., Appelo, C.A.J., 1999. User's Guide to PHREEQC (Version 2): A Computer Program for Speciation, Batch-reaction, One-dimensional Transport, and Inverse Geochemical Calculations.

Parkhurst, D.L., Kipp, K.L., 2002. Parallel processing for PHAST: a three-dimensional reactive-transport simulator. In: Majid Hassanizadeh, S., Schotting, Ruud J., Gray, William G., Pinder, George F. (Eds.), Developments in Water Science, Computational Methods in Water Resources Proceedings of the XIVth International Conference on Computational Methods in Water Resources 
(CMWR XIV). Elsevier, pp. 711-718. https://doi.org/10.1016/ S0167-5648(02)80128-9.

Parkhurst, D.L., Engesgaard, P., Kipp, K.L., 1995. Coupling the Geochemical Model PHREEQC With a 3D Multi-component Solute Transport Model. Presented at the Fifth Annual V.M. Goldschmidt Conference, Geochemical Society. Penn State University, University Park, USA.

Plaza, F., Wen, Y., Perone, H., Xu, Y., Liang, X., 2017. Acid rock drainage passive remediation: potential use of alkaline clay, optimal mixing ratio and long-term impacts. Sci. Total Environ. 576, 572-585.

Plummer, L.N., Wigley, T.M.L., Parkhurst, D.L., 1978. The kinetics of calcite dissolution in $\mathrm{CO}_{2}$-water systems at 5 degrees to 60 degrees $\mathrm{C}$ and 0.0 to $1.0 \mathrm{~atm} \mathrm{CO}_{2}$. Am. J. Sci. 278, 179-216. https://doi.org/10.2475/ajs.278.2.179.

Poulain, A., Goderniaux, P., de Dreuzy, J.-R., 2016. Study of Groundwater-quarry Interactions in the Context of Energy Storage Systems. Presented at the EGU General Assembly Conference Abstracts. 9055.

Pujades, E., Willems, T., Bodeux, S., Orban, P., Dassargues, A., 2016. Underground pumped storage hydroelectricity using abandoned works (deep mines or open pits) and the impact on groundwater flow. Hydrogeol. J. 24, 1531-1546. https://doi.org 10.1007/s10040-016-1413-z.

Pujades, E., Orban, P., Bodeux, S., Archambeau, P., Erpicum, S., Dassargues, A., 2017. Underground pumped storage hydropower plants using open pit mines: how do groundwater exchanges influence the efficiency?. Appl. Energy 190, 135-146. https://doi.org/10.1016/j.apenergy.2016.12.093.

Pujades, E., Orban, P., Jurado, A., Ayora, C., Brouyère, S., Dassargues, A., 2017. Water chemical evolution in underground pumped storage hydropower plants and induced consequences. Energy Procedia 125, 504-510. https://doi.org/10.1016/j. egypro.2017.08.174

Pujades, E., Jurado, A., Orban, P., Ayora, C., Poulain, A., Goderniaux, P., Brouyère, S., Dassargues, A., 2018. Hydrochemical changes induced by underground pumped storage hydropower and their associated impacts. J. Hydrol. 563, 927-941.

Pummer, E., Schüttrumpf, H., 2018. Reflection phenomena in underground pumped storage reservoirs. Water 10, 504. https://doi.org/10.3390/w10040504.

Robb, G.A., 1994. Environmental consequences of coal mine closure. Geogr. J. 160, 33-40. https://doi.org/10.2307/3060139.

Sánchez-España, J., Yusta, I., Diez-Ercilla, M., 2011. Schwertmannite and hydrobasaluminite: a re-evaluation of their solubility and control on the iron and aluminium concentration in acidic pit lakes. Appl. Geochem. 26, 1752-1774. https://doi.org/ 10.1016/j.apgeochem.2011.06.020.

Sanz, E., Ayora, C., Carrera, J., 2011. Calcite dissolution by mixing waters: geochemical modeling and flow-through experiments. Geol. Acta 9, 67-77. https://doi.org/ $10.1344 / 105.000001652$.

Severson, M.J., 2011. Preliminary Evaluation of Establishing an Underground Taconite Mine, to be Used Later as a Lower Reservoir in a Pumped Hydro Energy Storage Facility, on the Mesabi Iron Range, Minnesota.
Sharma, S., Sack, A., Adams, J.P., Vesper, D.J., Capo, R.C., Hartsock, A., Edenborn, H.M., 2013. Isotopic evidence of enhanced carbonate dissolution at a coal mine drainage site in Allegheny County, Pennsylvania, USA. Appl. Geochem. 29, $32-42$.

Spriet, J., 2014. A Feasibility Study of Pumped Hydropower Energy Storage Systems in Underground Cavities.

Tabelin, C.B., Veerawattananun, S., Ito, M., Hiroyoshi, N., Igarashi, T., 2017. Pyrite oxidation in the presence of hematite and alumina: I. Batch leaching experiments and kinetic modeling calculations. Sci. Total Environ. 580, 687-698.

Tabelin, C.B., Veerawattananun, S., Ito, M., Hiroyoshi, N., Igarashi, T., 2017. Pyrite oxidation in the presence of hematite and alumina: II. Effects on the cathodic an anodic half-cell reactions. Sci. Total Environ. 581-582, 126-135.

Tam, S.W., Blomquist, C.A., Kartsounes, G.T., 1979. Underground pumped hydro storage-an overview. Energy Sources 4 (4), 329-351.

White, A.F., Brantley, S.L., 1995. Chemical weathering rates of silicate minerals: an overview. Rev. Mineral. 31, 1-21.

Williamson, M.A., Rimstidt, J.D., 1994. The kinetics and electrochemical rate-determining step of aqueous pyrite oxidation. Geochim. Cosmochim. Acta 58 (24), 5443-5454.

Winde, F., Stoch, E.J., 2010. Threats and opportunities for postclosure development in dolomitic gold mining areas of the West Rand and Far West Rand (South Africa)-a hydraulic view part 1: mining legacy and future threats. Water SA 36, 69-74. https://doi.org/10.4314/wsa.v36i1.50908.

Winde, F., Stoch, E.J., 2010. Threats and opportunities for post-closure development in dolomitic gold-mining areas of the West Rand and Far West Rand (South Africa)-a hydraulic view part 2: opportunities. Water SA 36, 75-82. https://doi. org/10.4314/wsa.v36i1.50909.

Winde, F., Kaiser, F., Erasmus, E., 2017. Exploring the use of deep level gold mines in South Africa for underground pumped hydroelectric energy storage schemes. Renew. Sust. Energ. Rev. 78, 668-682.

Wong, I.H., 1996. An underground pumped storage scheme in the Bukit Timah Granite of Singapore. Tunn. Undergr. Space Technol. 11, 485-489. https://doi.org/10. 1016/S0886-7798(96)00035-1.

Xu, K., Dai, G., Duan, Z., Xue, X., 2018. Hydrogeochemical evolution of an Ordovician limestone aquifer influenced by coal mining: a case study in the Hancheng mining area, China. Mine Water Environ. 1-11.

Zhang, N., Lu, X., McElroy, M.B., Nielsen, C.P., Chen, X., Deng, Y., Kang, C., 2016. Reducing curtailment of wind electricity in China by employing electric boilers for heat and pumped hydro for energy storage. Appl. Energy 184, 987-994. https:// doi.org/10.1016/j.apenergy.2015.10.147.

Zillmann, A., Perau, E., 2015. A conceptual analysis for an underground pumped storage plant in rock mass of the Ruhr region. Geotech. Eng. Inf. Dev. 3789-3794. https://doi.org/10.1680/ecsmge.60678.vol7.597. 